\title{
Waktu Penggunaan Kontrasepsi Pil Kombinasi yang Berhubungan dengan Kasus Kenaikan Tekanan Darah dalam Wilayah Kerja Puskesmas Martapura I Kabupaten Banjar Provinsi Kalimantan Selatan
}

\author{
Nirwana Per - Angin2 ${ }^{1^{*}}, \mathrm{Hj}$. Isnaniah ${ }^{2}$ \\ $1^{*}, 2$ Dosen Poltekkes Kemenkes Banjarmasin \\ *corresponding author \\ Nirwana Per-Angin2 \\ nirwanaperangin2bjm@gmail.com
}

\begin{abstract}
Abstrak
Penggunaan Kontrasepsi pil kombinasi merupakan salah satu penyebab terjadinya kenaikan tekanan darah terutama di wilayah kerja Puskesmas Martapura I Kabupaten Banjar Provinsi Kalimntan Selatan yakni sebesar 26,32\%. Penelitian ini dilaksanakan dengan tujuan mengetahui waktu penggunaan kontrasepsi pil kombinasi yang berhubungan dengan kasus kenaikan tekanan darah dalam wilayah kerja Puskesmas Martapura I Kabupaten Banjar Provinsi Kalimantan Selatan. Metoda yang digunakan dalam penelitian ini adalah survei analitik dengan pendekatan cross sectional. Popuasi dalam penelitian ini sebanyak 234 akseptor dan sampel sebayak 71 akseptor degan menggunakan teknik Purposive Sampling. Analisis yang digunakan adalah uji Chi Square dengan $\alpha 0,05$. Hasil penelitian didapatkan $p=0,002$. Kesimpulan pada penelitian ini di dapatkan bahwa ada hubungan antara waktu penggunaan kontrasepsi pil kombinasi dengan kasus kenaikan tekanan darah.
\end{abstract}

Kata kunci: Kenaikan tekanan darah; Lama penggunaan kontrasepsi pil kombinasi

\section{Time for The Use of Combination Pill Contraception Related to The Case of Blood Pressure in The Scope of The Martapura I Health Center of Banjar District, South Kalimantan Province}

\begin{abstract}
The use of combined pill contraception is one of the causes of an increase in blood pressure, especially in the working area of Martapura I Public Health Center, Banjar Regency, South Kalimantan Province, which is $26.32 \%$. This study was conducted with the aim of knowing the Time of Use of Combination Pill Contraception Related to the Case of Increasing Blood Pressure in the Work Scope of Martapura I Public Health Center, Banjar Regency, South Kalimantan Province. The method used in this research is analytic survey with cross sectional approach. The population in this study were 234 acceptors and samples
\end{abstract}


Waktu Penggunaan Kontrasepsi Pil Kombinasi yang Berhubungan dengan Kasus Kenaikan Tekanan Darah dalam Wilayah Kerja Puskesmas Martapura I Kabupaten Banjar Provinsi Kalimantan Selatan

were 71 acceptors using the Purposive Sampling technique. The analysis used was the Chi Square test with $\alpha 0.05$. The research results obtained $p=0.002$. The conclusion of this study is that there is a relationship between the time of use of combined pill contraception with a case of increased blood pressure.

Keyword: Increase in Blood Pressure; Duration of Use of Combination Pill Contraception

Pendahuluan

Jumlah penduduk di Indonesia masih sangat tinggi saat ini menempati peringkat ke- 5 dunia. Ada tiga faktor yang mempengaruhi laju pertumbuhan penduduk yaitu fertilitas, mortalitas dan migrasi. Salah satu usaha Pemerintah mengantisipasi tingginya pertumbuhan penduduk adalah dengan penggunaan kontrasepsi pil kombinasi. (Kementerian Kesehatan RI, 2014).

Berdasarkan tingginya angka kejadian kenaikan tekanan darah pada saat dilakukan studi pendahuluan pada 10 akseptor pil kombinasi yakni 5 akseptor diantaranya $(50 \%)$ mengalami kenaikan tekanan darah. Pemakaian kontrasepsi pil di Kabupaten Banjar dominan yaitu 46.494 atau 50,58\% dari 91.435 peserta KB aktif dan di Kecamatan Martapura 1 pemakaian alat kontrasepsi pil mencapai 6755 $(45,81 \%)$ dari 14.745 peserta KB aktif (Everett, 2012).
Kelompok Wanita Subur (WUS) yang berada pada kisaran usia 15-49 tahun menjadi titik berat sasaran pelaksanaan Program KB pada Pasangan Usia Subur (PUS). Berdasarkan hasil survei tahun 2015 peserta program KB baru dan yang aktif di Indonesia ditemukan pola yang identik dalam pemilihan jenis alat kontrasepsi yaitu jenis suntikan dan pil. Bila hasil survei tersebut dibandingkan dengan survei ditahun 2014 maka ditemukan hasil bahwa tidak ada perubahan yang signifikan dalam pemilihan jenis alat kontrasepsi KB. Hal itu disebabkan oleh pil dan suntikan dianggap sebagai alat kontrasepsi yang lebih mudah diperoleh dan digunakan oleh akseptor (Kementerian Kesehatan RI, 2014).

Ada tiga jenis pil kontrasepsi KB yaitu pil yang hanya berisi hormon progesteron, pil yang hanya berisi hormon estrogen dan pil yang berisi kombinasi antara hormon estrogen 
Waktu Penggunaan Kontrasepsi Pil Kombinasi yang Berhubungan dengan Kasus Kenaikan Tekanan Darah dalam Wilayah Kerja Puskesmas Martapura I Kabupaten Banjar Provinsi Kalimantan Selatan

dan progesteron (Kementerian Kesehatan RI, 2015).

Hasil Survei Demografi dan Kesehatan Indonesia 2012 selama menggunakan kontrasepsi pil masih dijumpai sekitar (5,5\%) perempuan yang mengalami masalah kesehatan diantaranya masalah yang paling umum adalah sakit kepala (2\%) dan hipertensi (0,2\%) (Kementerian Kesehatan RI, 2016).

Penelitian

penggunaan

kontrasepsi pil dihubungkan dengan riwayat keluarga yang mengalami hipertensi pada PUS diperoleh hasil 14 kali lebih besar mengalami resiko kejadian hipertensi pada akseptor yang menggunakan kontrasepsi pil kombinasi (Lamria P dan Lolong D.B, 2015).

Hipertensi memiliki dua faktor risiko yaitu faktor risiko hipertensi yang dapat diubah dan faktor risiko hipertensi yang tidak dapat diubah. Faktor risiko yang tidak dapat berubah adalah umur, jenis kelamin, genetik dan ras sedangkan faktor risiko hipertensi yang dapat diubah adalah obesitas/kegemukan, psikososial dan stres, merokok, pendidikan, olahraga yang kurang, konsumsi alkohol berlebihan, konsumsi garam berlebihan, dyslipidemia, kopi (kafein),
Obat Anti Inflamasi Nonsteroid (OAIN), serta penggunaan kontrasepsi pil (Leonard E, 2013). Berdasarkan hasil mini survei dari Badan Koordinasi Keluarga Berencana Nasional (BKKBN) pada tahun 2015 diperoleh hasil bahwa prevalensi peserta KB di Indonesia adalah $75,10 \%$. Berdasarkan tingginya pemakaian alat kontrasepsi pil sebanyak 6755 (45,81\%) dari 14.745 peserta KB aktif dan tingginya angka kejadian hipertensi dengan jumlah kasus 6.268 (26,32\%) di Martapura I serta hasil studi pendahuluan di Wilayah Kerja Puskesmas Martapura I. (Buku Register Laporan Penyakit Tidak Menular, 2016).

Hasil pendataan Riskesdes prevalensi hipertensi berdasarkan jenis kelamin tahun 2007 yaitu laki-laki $31,3 \%$ wanita $31,9 \%$, pada tahun 2013 laki-laki 22,8\% dan wanita $28,8 \%$. Dari hasil tersebut dapat ditarik kesimpulan bahwa dibandingkan dengan laki-laki perempuan memiliki prevalensi hipertensi yang lebih tinggi. Berdasarkan hasil Survei Riset Dasar Kesehatan yang dilaksanakan pada tahun 2013, Provinsi Kalimantan Selatan merupakan wilayah dengan prevalensi kejadian hipertensi tertinggi 
Waktu Penggunaan Kontrasepsi Pil Kombinasi yang Berhubungan dengan Kasus Kenaikan Tekanan Darah dalam Wilayah Kerja Puskesmas Martapura I Kabupaten Banjar Provinsi Kalimantan Selatan

yaitu 30,8\% dibandingkan dengan provinsi lain di Kalimantan. Profil Dinas Kesehatan Kabupaten Banjar 2015 menyebutkan bahwa penyakit hipertensi menempati urutan kedua untuk penyakit terbanyak pada pasien yang datang ke Puskesmas yaitu 21,49\%. Kecamatan Martapura I merupakan kecamatan dengan kasus hipertensi paling tinggi dari daerah lain dengan jumlah kasus 6.268 (26,32\%). (Notoatmodjo S, 2010).

Hasil studi pendahuluan di wilayah kerja Puskesmas Martapura I, dari 10 akseptor kontrasepsi pil diperoleh informasi bahwa akseptor kontrasepsi pil dengan penggunaan < 4 tahun terdapat 3 akseptor (30\%) yang tidak mengalami peningkatan tekanan darah/hipertensi, sedangkan akseptor kontrasepsi pil dengan penggunaan $\geq 4$ tahun terdapat 5 akseptor (50\%) yang mengalami peningkatan tekanan darah dan 2 akseptor (20\%) yang tidak mengalaminya (Jafar N, 2010).

Penelitian dilaksanakan untuk mengetahui resiko waktu penggunaan kontrasepsi pil kombinasi yang berhubungan dengan kasus kenaikan tekanan darah dalam lingkup kerja Puskesmas Martapura I Kabupaten Banjar Provinsi Kalimantan Selatan.

\section{Metode}

Penelitian ini dalam pelaksanaannya menggunakan desain cross sectional, dan dilaksanakan di wilayah kerja Puskesmas Martapura I Kabupaten Banjar dari bulan Juli 2019 sampai dengan oktober 2019. Pemilihan populasi pada penelitian ini adalah seluruh akseptor kontrasepsi pil kombinasi sebanyak 234 akseptor (Notoatmdjo,2010).

Teknik pengambilan sampel pada penelitian ini adalah purposive sampling yaitu didasarkan pada suatu pertimbangan tertentu yang dibuat oleh peneliti sendiri, berdasarkan ciri atau sifat-sifat populasi yang sudah diketahui sebelumnya (Notoatmdjo,2010).

Sampel pada penelitian ini adalah akseptor kontrasepi pil kombinasi yang berkunjung ke Puskesmas Martapura I sebanyak 71 orang, jika sampel tidak mencukupi kuota pada waktu yang telah ditentukan akan dilakukan kunjungan rumah (Suyanto dan Salamah, 2008). Analisis yang digunakan adalah Uji Chi Square (Ridwan \& Akdon, 2010).

\section{Hasil dan Pembahasan}


Waktu Penggunaan Kontrasepsi Pil Kombinasi yang Berhubungan dengan Kasus Kenaikan Tekanan Darah dalam Wilayah Kerja Puskesmas Martapura I Kabupaten Banjar Provinsi Kalimantan Selatan

Analisis Univariat

Tabel 1. Sebaran Frekuensi Berdasarkan Waktu Penggunaan Kontrasepsi Pil Kombinasi Akseptor Pil di Wilayah Kerja Puskesmas Martapura I Tahun 2019

\begin{tabular}{ccc}
\hline $\begin{array}{c}\text { Lama Penggunaan } \\
\text { Kontrasepsi Pil } \\
\text { Kombinasi }\end{array}$ & Frekuensi & $\%$ \\
\hline 24tahun & 25 & 35,2 \\
$<4$ tahun & 46 & 64,8 \\
\hline Total & 71 & 100,0 \\
\hline
\end{tabular}

Sumber: Buku Register KB

Berdasarkan tabel 1 paling

banyak menggunakan pil kombinasi yakni dari 71 responden terdapat 46 responden $(64,8 \%)$ dan $\geq 4$ tahun sebanyak 25 responden (35,2\%).

Tabel 2. Sebaran Frekuensi Berdasarkan Kejadian Kenaikan Tekanan Darah Akseptor Pil Kombinasi di Wilayah Kerja Puskesmas Martapura I Tahun 2019

\begin{tabular}{ccc}
\hline $\begin{array}{c}\text { Kejadian Kenaikan } \\
\text { Tekanan Darah }\end{array}$ & Frekuensi & $\%$ \\
\hline $\begin{array}{c}\text { Tekanan Darah } \\
\text { Meningkat }\end{array}$ & 47 & 66,2 \\
$\begin{array}{c}\text { Tekanan Darah Tidak } \\
\text { Meningkat }\end{array}$ & 24 & 33,8 \\
\hline Jumlah & 71 & 100 \\
\hline $\begin{array}{c}\text { Sumber : Buku Reister KB } \\
\text { Berdasarkan tabel }\end{array}$ & 2 & paling
\end{tabular}

banyak mengalami kenaikan tekanan darah yakni dari 71 reponden terdapat 47 reponden $(66,2 \%)$ dan yang tidak mengalami kenaikan tekanan darah sebanyak 24 responden (33,8\%).

\section{Analisis Bivariat}

Tabel 3. Hubungan Waktu Penggunaan Kontrasepsi Pil Kombinasi dengan Kejadian Tekanan Darah di Wilayah Kerja Puskesmas Martapura I Kabupaten Banjar Tahun 2019.

\begin{tabular}{|c|c|c|c|c|c|c|}
\hline \multirow{3}{*}{$\begin{array}{c}\text { Lama } \\
\text { Penggunaan } \\
\text { Kontrasepsi } \\
\text { Pil } \\
\text { Kombinasi }\end{array}$} & \multicolumn{6}{|c|}{ Kejadian kenaikan Tekanan Darah } \\
\hline & \multicolumn{2}{|c|}{$\begin{array}{l}\text { Tekanan } \\
\text { Darah } \\
\text { Meningkat }\end{array}$} & \multicolumn{2}{|c|}{$\begin{array}{l}\text { Tekanan } \\
\text { Darah } \\
\text { Tidak } \\
\text { Meningkat }\end{array}$} & \multicolumn{2}{|c|}{ TOTAL } \\
\hline & $\mathrm{N}$ & $\%$ & $\mathrm{~N}$ & $\%$ & $\mathrm{~N}$ & $\%$ \\
\hline$\geq 4$ ta & 23 & 92,0 & 2 & 8,0 & 25 & 100 \\
\hline$<4$ tahun & 24 & 52,2 & 22 & 47,8 & 46 & 100 \\
\hline Jumlah & 47 & 66,2 & 24 & 33,8 & 71 & 100 \\
\hline
\end{tabular}

Uji Chi-Squarep $=0,002(p<a 0,05)$ OR 10,5, $\mathrm{Cl}(95 \%): 2,2-14,9$

Sumber : Buku Register KB
Dari tabel 3 di atas didapatkan hasil bahwa 71 responden dengan waktu penggunaan kontrasepsi pil kombinasi $\geq 4$ tahun, sebanyak 23 responden $(92,0 \%)$ yang mengalami kejadian tekanan darah/hipertensi dan 2 responden (8,0\%) yang tidak mengalami kejadian kenaikan tekanan darah/hipertensi, sedangkan 46 responden yang lama penggunaan kontrasepsi pil kombinasi $<4$ tahun ada 24 responden (52,2\%) yang mengalami kejadian kenaikan tekanan darah/hipertensi dan 22 responden $(47,8 \%)$ yang tidak mengalami kejadian tekanan darah/hipertensi. Hasil uji statistik Chi-Square dengan nilai kemaknaan $\alpha=0,05$ menggunakan Continuity Correction diperoleh nilai probabilitas $(p)=0,002$ dengan demikian nilai $(p)=0,002<(\alpha)$ $=0,05$ yakni rnenunjukkan bahwa ada hubungan waktu penggunaan kontrasepsi pil kombinasi dengan kejadian kenaikan tekanan darah di Wilayah Kerja Puskesmas Martapura I. Nilai OR 10,5 (Cl 95\%: 2,2-14,9) artinya waktu penggunaan kontrasepsi $\geq 4$ tahun memiliki peluang sebesar 10,5 kali mengalami kejadian kenaikan tekanan darah dibandingkan dengan waktu penggunaan $<4$ tahun. 
Waktu Penggunaan Kontrasepsi Pil Kombinasi yang Berhubungan dengan Kasus Kenaikan Tekanan Darah dalam Wilayah Kerja Puskesmas Martapura I Kabupaten Banjar Provinsi Kalimantan Selatan

Penggunaan kontrasepsi pil kombinasi akan menyebabkan adanya peningkatan ringan terhadap tekanan darah sistolik dan diastolik, hal tersebut terutama akan berlangsung pada 2 tahun pertama. Akseptor pil kombimasi sebayak 2 - $\geq$ $4 \%$ akan mengalami kenaikan tekanan darah, khususnya yang mengandung etilestradiol. Hal tersebut berhubungan erat antara usia akseptor dengan waktu penggunaan. Hasil penelitian sebelumnya menunjukkan bahwa setelah $\geq 4$ tahun penggunaan kontrasepsi pil kombinasi, yang mengandung estrogen dan progesteron, akseptor akan mengalami peningkatan tekanan darah 2-3 kali lipat (Nafisah D, Wahyudi P dan Ramani A, 2014).

Hasil penelitian didapatkan bahwa dari 25 responden dengan lama penggunaan kontrasepsi pil kombinasi $\geq 4$ tahun sebanyak 23 responden $(92,0 \%)$ yang mengalami kejadian kenaikan tekanan darah, sedangkan dari 46 responden yang waktu penggunaan kontrasepsi pil kombinasi $<4$ tahun ada 24 responden $(52,2 \%)$ yang mengalami kejadian peningkatan tekanan darah (Notoatmodjo, 2010).
Penelitian ini dapatkan hasil yang sejalan dengan penelitian yang dilakukan oleh Nafisah, Wahjudi dan Ramani (2014) yang berjudul "Faktor yang Berhubungan dengan Kejadian Hipertensi pada Akseptor Pil Keluarga Berencana di Kelurahan Sumbersari Kabupaten Jember Tahun 2014". Peneltian ini mendapatkan hasil bahwa terdapat hubungan/korelasi antara umur dan waktu penggunaan pil KB. Penelitian menggunakan studi cross sectional dan menggunakan analisis dengan uji Chi-Square dengan $\mathrm{Cl} 5 \% \quad(\mathrm{a}=0,05)$. Sampel adalah 70 wanita yang menggunakan pil KB minimal 2 tahun terakhir.

Penelitian oleh Lamria Pangaribuan (2015) yang berjudul "Hubungan Penggunaan Kontrasepsi Pil dengan Kejadian Kenaikan Hipertensi pada Wanita Usia 15-49 Tahun di Indonesia Tahun 2013". Penelitian ini mendapatkan hasil bahwa terdapat hubungan yang erat antara penggunaan kontrasepsi pil dengan kejadian hipertensi pada usia 15-49 tahun dengan nilai PR1,4 $(95 \% \mathrm{Cl}: 1,31-1,45)$ setelah dilakukan control umur dan IMT. Penelitian menggunakan studi Cross Sectional dengan uji analisis Cox Regression. Wanita usia 15-49 tahun yang 
Waktu Penggunaan Kontrasepsi Pil Kombinasi yang Berhubungan dengan Kasus Kenaikan Tekanan Darah dalam Wilayah Kerja Puskesmas Martapura I Kabupaten Banjar Provinsi Kalimantan Selatan

berjumlah sebanyak 34.755 orang

dijadikan sampel pada penelitian ini.

Penelitian Tatali, Kundre dan Bataha (2016) dengan yang berjudul "Hubungan Penggunaan Kontrasepsi Pil KB Kombinasi dengan Hipertensi pada Akseptor Pil KB di Puskesmas Enemawira Kabupaten Sangihe". Penelitian memperoleh hasil penggunaan pil KB kombinasi berhubungan dengan hipertensi pada akseptor pil KB. Akseptor Pil KB Kombinasi memiliki resiko 39.000 kali mengalami Hipertensi. Penelitian ini menggunakan studi Cross Sectional dengan uji analisis Chi Square dengan $\mathrm{Cl} 5 \%(a=0,05)$. Sampel berjumlah 65 responden dengan teknik Total Sampling.

\section{Simpulan}

Berdasarkan hasil penelitian tentang waktu penggunaan kontrasepsi pil kombinasi berhubungan dengan kasus kenaikan tekanan darah dalam wilayah kerja Puskesmas Martapura I Kabupaten Banjar, dapat disimpulkan sebagai berikut

1. Akseptor pil kombinasi yang mengalami kenaikan tekanan darah sebanyak 47 responden $(66,2 \%)$ dari 71 responden.
2. Waktu penggunaan kotrasepsi pil kombinasi $\geq 4$ tahun sebanyak 25 responden $(35,2 \%)$ dan $<4$ tahun sebanyak 46 responden $(64,8 \%)$ dari 71 responden.

3. Waktu penggunanaan kontrasepsi pil berhubungan dengan kejadian kenaikan tekanan darah ( $p 0,002: \alpha, 0,05)$ dan $\mathrm{OR}=10,5$. Risiko waktu penggunaan $\geq 4$ tahun memiliki peluang kejadian kenaikan tekanan darah sebesar 10,5 kali lipat.

\section{Daftar Pustaka}

Buku Register Puskesmas Martapura Kota. Laporan Penyakit Tidak Menular Puskesmas Martapura Kota Januari - Desember 2015. Martapura: 2016.

Everett, S. (2012). Buku Saku Kontrasepsi dan Kesehatan Seksual Reproduktif, Edisi 2. Penerjemah Brahm U. Jakarta : EGC. p. 118-152.

Jafar, N. (2010). Hipertensi. Universitas Hasanuddin FKM UNHAS. Available from: $<$ respitory.unhas.ac.id> (Acessed 20 Desember 2016).

Kementerian Kesehatan RI. (2014). Info dan Situasi dan Analisis Keluarga Berencana.Jakarta. $p$. 2-4

Kementerian Kesehatan RI. (2015). Profi IKesehatan Indonesia Tahun 2014.Jakarta. p. 103-106.

Kementerian Kesehatan RI. (2016). 
Waktu Penggunaan Kontrasepsi Pil Kombinasi yang Berhubungan dengan Kasus Kenaikan Tekanan Darah dalam Wilayah Kerja Puskesmas Martapura I Kabupaten Banjar Provinsi Kalimantan Selatan

Profil Kesehatan Indonesia Tahun 2015. Jakarta. p. 120125.

Lamria, P. \& Lolong, D, B. (2015). Hubungan Penggunaan Kontrasepsi Pil dengan Kejadian Hipertensi pada Wanita Usia 1549 Tahun di Indonesia Tahun 2013 (Analisis Data Riskesdas 2013). Available from: $<$ http://download.portalgaruda.o $\mathrm{rg} / \mathrm{>}$. (Acessed 28 November 2016).

Leonard E. (2013). Epidemiologi dan Faktor Risiko Hipertensi. In:Pikir, B.S. (Ed). Hipertensi Manajemen Komprehensif. Surabaya: Airlangga University Press.

Nafisah, D., Wahjudi, P., Ramani, A. (2014). E-Jurnal Pustaka Kesehatan. Faktor yang Berhubungan dengan Kejadian Hipertensi pada Akseptor Pil KB di Kelurahan Sumbersari Kabupaten Jember. Vol. 2 No. 3. Available from: http: $/ /<$ repository.unej.ac.id $>$. (Accessed 28 November 2016)

Notoatmodjo. 2010. Metodologi Penelitian Kesehatan. Jakarta:Rineka Cipta. p. 37, 100, 171, 201.

Ridwan \& Akdon. (2010). Rumus dan Data dalam Analisis Statistika. Bandung: Alfabeta. p. 69.

Suyanto \& Salamah, U. (2008). Riset Kebidanan Metodelogi dan Aplikasi. Yogyakarta: Mitra Cendikia.

Tatali, C, S., Kundre, R, M., Bataha, Y, M. (2016). E-Jurnal Keperawatan. Hubungan Penggunaan Konrasepsi Pil KB Kombinasi dengan Hipertensi pada Akseptor Pil KB di
Puskesmas Enemawira Kabupaten Sangihe. Vol. 4 No. 1. Available from:<ejournal.unsrat.ac.id $>$. 